\title{
Surface markers of lymphocyte activation in pregnant asthmatics
}

\author{
Anikó Bohács · Éva Pállinger · Lilla Tamási · János Rigó Jr. • \\ Zsolt Komlósi · Veronika Müller · Yang Dong · Pál Magyar · \\ András Falus · György Losonczy
}

Received: 5 April 2009/Revised: 2 July 2009/Accepted: 16 July 2009/Published online: 28 August 2009

(C) The Author(s) 2009. This article is published with open access at Springerlink.com

\begin{abstract}
Problem Pregnancy-associated immunologic alterations may improve the course of asthma. Severe maternal asthma with an exacerbation impairs fetal growth.

Method of study Lymphocyte activation was estimated by flow cytometry analysis of surface markers in non-pregnant healthy and mild or moderate persistent asthmatic women and healthy as well as mild or moderate persistent asthmatic, third trimester pregnant women.

Results Compared with non-pregnant healthy subjects $(n=12)$ activated pools within CD4 and CD8 T cells were larger and the number of NK T cells were increased both in
\end{abstract}

Responsible Editor: C. Kasserra.

A. Bohács · L. Tamási - Z. Komlósi · V. Müller · P. Magyar ·

G. Losonczy ( $\square)$

Department of Pulmonology, Semmelweis University,

Diós árok u. 1/c, 1125 Budapest, Hungary

e-mail: losonczy@pulm.sote.hu

A. Bohács

e-mail: szatmari-bohacs@freemail.hu

É. Pállinger · A. Falus

Department of Genetics and Cell- and Immunobiology,

Semmelweis University, Budapest, Hungary

J. Rigó Jr.

Ist Department of Obstetrics and Gynecology,

Semmelweis University, Budapest, Hungary

Y. Dong

First Affiliated Hospital of Dalian Medical University,

Dalian, People's Republic of China

A. Falus

Inflammation Biology and Immunogenomics Research Group,

Hungarian Academy of Sciences, Budapest, Hungary non-pregnant asthmatic $(n=12)$ and in healthy pregnant $(n=13)$ subjects (all $p<0.05)$. No further lymphocyte activation was observed in pregnant asthmatics $(n=21)$ compared either with non-pregnant asthmatic, or pregnant healthy women. Average birth weight of newborns was lower $(p<0.05)$ in the asthmatic than in the healthy pregnant group.

Conclusion Pregnancy is a state of wide-spread lymphocyte activation but it may blunt lymphocyte activation which characterizes bronchial asthma.

Keywords Asthma - Flow cytometry .

Immunotolerance $\cdot$ Lymphocyte activation · Pregnancy

$\begin{array}{ll}\text { Abbreviations } \\ \text { BMI } & \text { Body mass index } \\ \mathrm{FEV}_{1} & \text { Forced expiratory volume in 1-s } \\ \mathrm{GINA} & \text { Global initiative for asthma } \\ \mathrm{PEF} & \begin{array}{l}\text { Peak expiratory flow } \\ \mathrm{pCO}_{2}\end{array} \\ \begin{array}{l}\text { Partial pressure of carbon-dioxide in arterialized } \\ \text { capillary blood }\end{array} \\ \mathrm{pO}_{2} \quad \begin{array}{l}\text { Partial pressure of oxygen in arterialized capillary } \\ \text { blood }\end{array} \\ \mathrm{Raw} & \text { Airway resistance }\end{array}$

\section{Introduction}

Extrinsic bronchial asthma is induced by allergic airway inflammation, where allergen activated $\mathrm{T}$ and $\mathrm{B}$ lymphocytes play important pathogenetic roles [1]. Lymphocyte activation in asthma is reflected by increased subpopulations that express various activation markers on the cell surface. Once a lymphocyte becomes activated certain 
surface antigens (clusters of differentiation, CDs) appear on the membrane, for example the major histocompatibility complex antigen HLA-DR [2-4], the apoptosis inducing domain Fas (CD95, [5]), the interleukin-2 (IL-2) receptor (CD25, [2-4]), the co-stimulatory molecule CD28 [6], and adhesion molecules such as intercellular adhesion molecule-1 (ICAM-1, CD54, [7]). Other integrins including Mac-1 (CD11b) and the transferrin receptor $(\mathrm{CD} 71)$ are also expressed on both the surface of $\mathrm{T}$ and $\mathrm{B}$ cells upon activation [8]. The intensity of lymphocyte activation correlates with the severity of airway symptoms in asthmatic patients $[2,4,9,10]$.

More women than men suffer from asthma [11] and the natural course of asthma is frequently modified by pregnancy [12]. In about one-third of pregnant asthmatics respiratory symptoms improve, in another third symptoms remain unchanged, and in the remaining third asthma worsens during pregnancy [13]. The cause of this variability is unknown and may be mostly immunologic in nature [14]. Pregnancy is known to interfere with the natural course of immunologic diseases such as rheumatoid arthritis [15, 16], or autoimmune thyroiditis [17]. Symptoms of these autoimmune diseases improve or remission may even occur during pregnancy before postpartum relapse.

Previous studies on $\mathrm{T}$ cell numbers and function during normal pregnancy reveal definite signs of both activation and hyporesponsiveness (anergy, clonal deletion) [18]. Kühnert et al. [19] and Mahmoud et al. [20-22] demonstrated significantly increased numbers of surface HLA$\mathrm{DR}^{+}, \mathrm{CD} 25^{+}$and $\mathrm{CD} 54^{+} \mathrm{CD} 4$ and $\mathrm{CD} 8$ lymphocytes in peripheral blood of healthy pregnant women. Other authors $[23,24]$ also reported higher fractions of $\mathrm{CD}^{+} 4^{+}$and $\mathrm{CD}_{11 \mathrm{~b}^{+}} \mathrm{CD} 4$ and CD8 lymphocytes in peripheral blood and also in decidua, where activated lymphocytes may play essential roles in the maintenance of placental growth and differentiation $[25,26]$.

Pregnancy primes the maternal immune system (both B and $\mathrm{T}$ cells) against paternal human leukocyte antigens of the fetus [27]. The mechanism of immunological tolerance to the fetus and placenta has been extensively studied [28]. The fetoprotective role of maternal regulatory $\mathrm{T}$ cells (Tregs) is thought to be crucial [29]. Oestradiol has been shown to potentiate the suppressive function of human Tregs by promoting their antigen independent proliferation [30]. Therefore, pregnancy may be a state of enhanced immunotolerance and remission of autoimmune disease may be explained by a "bystander" or "linked" blunting of lymphocyte activation of pathological importance.

Based on these considerations, in the present study we compared the size of activated subsets within various lymphocyte populations, T cells (CD4 and CD8), NK T cells, B lymphocytes and NK cells in pregnant and agematched non-pregnant women suffering from asthma of similar degree. Age-matched healthy pregnant and healthy non-pregnant women were included as control subjects.

\section{Methods}

Subjects

This study included 21 asthmatic pregnant women in their second and third trimesters of pregnancy (second trimester: $n=11$, third trimester: $n=10$ ) with mean age of $31.7 \pm 1.0$ (mean \pm SEM) years. They had routine obstetrical control at the Ist Department of Obstetrics and Gynecology, Semmelweis University, and were referred to the Asthma Outpatient Clinic, Department of Pulmonology, Semmelweis University, if history of asthma was reported. At the time of examination no asthmatic patient was experiencing exacerbation. Venous blood was drawn for routine laboratory tests and also for introduction into heparinized test tubes for flow cytometric analysis of lymphocytes, as published earlier [14]. Spirometry, whole body plethysmography and arterialized capillary blood gas and acid-base were analyzed. Asthma Control Test was recorded. Patients with clear evidence of respiratory tract infection (fever, purulent sputum, positive culture of sputum and need for antibiotic treatment) were excluded.

Three groups of control subjects were included: healthy pregnant women $(n=13)$ with mean age of $29.6 \pm$ 1.0 years and similar gestational age (seven women in the second and six women in the third trimester), healthy nonpregnant $(n=10)$ with mean age of $29.7 \pm 1.5$ years and asthmatic non-pregnant women $(n=12)$ with mean age of $31.5 \pm 1.5$ years. All patients were atopic and non-smoking. Asthmatic non-pregnant women were monitored at the Asthma Outpatient Clinic, Department of Pulmonology, Semmelweis University.

Asthmatic pregnant and non-pregnant women had mild to moderate persistent asthma as defined by the Global Initiative for Asthma (GINA) [31]. The onset and severity of asthma, previous results of skin prick tests with inhaled allergens, anti-asthma medications and changes of asthmatic symptoms during pregnancy were recorded. None of them were on systemic steroid 6 weeks prior to the visit or during pregnancy. Short-, or long-acting $\beta_{2}$-agonist and inhaled steroids had been used as anti-asthma treatments. At the time of pulmonary examination and blood withdrawal three patients from the asthmatic non-pregnant group and 10 women in the asthmatic pregnant group had not been receiving inhaled steroid. 
Analysis of activated lymphocyte subpopulations

Peripheral venous blood was collected by venipuncture, using the Becton-Dickinson (BD, San Jose, CA, USA) Vacutainer ${ }^{\circledR}$ Heparin Tubes. Immunophenotypic analysis was performed on the day of sample collection. All antibodies used for the characterization of different cell populations were manufactured by $\mathrm{BD}$ Biosciences Pharmingen. The "Direct Immunofluorescence Staining of Cells Using a Lyse/Wash Procedure" protocol of BD Biosciences [32] was used for staining the cell surface antigens. Before the measurements, cells were fixed by $2 \%$ paraformaldehyde solution (Sigma-Aldrich, St. Louis, MO, USA). Multicolor staining procedure was used for the detection of lymphocyte subsets as indicated in Table 1 The percentual ratio of lymphocyte subsets was related to the lymphocyte gate. The lymphocyte gate was determined according to the size and granulation by the FS/SS dot plot. The purity of the gate was detected by CD45/CD14 labeling. The lymphocyte gate was set considering the amount of $\mathrm{CD}^{2} 5^{+}$lymphocytes (more than 95\%) and the ratio of $\mathrm{CD} 45^{+} / \mathrm{CD} 14^{+}$monocytes (less than 3\%). Isotype control antibodies were used for the detection of aspecific staining.

Measurements were carried out using a FACSCalibur flow cytometer (BD) on the day of the staining, collecting $2.5 \times 10^{4}-1 \times 10^{5}$ cells/tube. CellQuest-Pro Software (BD) was used for analysis.
The absolute numbers of cells and their subsets in clinical samples were assessed using dual-platform counting technologies, which couples the percentage of positive cell subsets counted by flow cytometry and the absolute cell count measured by automated hematology analyzer (Cell-Dyne 3200, Abbott) [33].

\section{Statistics}

Data are shown as means \pm SEM. Statistical analysis was performed by ANOVA and if there was significant $(p<0.05)$ difference among the four groups, the Newman-Keuls multiple comparison post-hoc test was used for further analysis. Post-hoc pair-wise comparisons were carried out between the following groups: 1. asthmatic non-pregnants versus healthy non-pregnants 2 . healthy pregnants versus healthy non-pregnants 3. asthmatic pregnants versus healthy pregnants. The unpaired $t$ test and Fischer's exact test were used where indicated. Correlations were analysed by multiple linear regression.

\section{Results}

\section{Clinical data}

The mean age of study groups was around 29-32 years, with no significant difference between them (Table 2).
Table 1 Characterization of circulating lymphocyte subpopulations by immunophenotyping

\begin{tabular}{llll}
\hline FITC & Pe & PerCP or Cy-chrome & APC \\
\hline Isotype control Ab & Isotype control Ab & Isotype control Ab & Isotype control Ab \\
CD25 & CD8 & CD4 & CD3 \\
CD71 & CD152 & CD19 & CD3 \\
CD56 & HLA-DR & CD16 & CD3 \\
CD45 & CD14 & & \\
CD28 & CD54 & CD4 & CD11b \\
CD28 & CD54 & CD8 & CD11b \\
\hline
\end{tabular}

Table 2 Age and obstetrical data of subjects (means \pm SEM)

\begin{tabular}{lllll}
\hline & Healthy non-pregnant & Asthmatic non-pregnant & Healthy pregnant & Asthmatic pregnant \\
\hline Number & 10 & 12 & 13 & 21 \\
Age (year) & $29.0 \pm 1.6$ & $31.4 \pm 1.7^{\mathrm{ns}}$ & $29.6 \pm 1.1^{\mathrm{ns}}$ & $31.7 \pm 1.0^{\mathrm{ns}}$ \\
BMI $\left(\mathrm{kg} / \mathrm{m}^{2}\right.$ ) & $20.6 \pm 0.44$ & $25.02 \pm 1.45^{\mathrm{a}}$ & $24.77 \pm 0.55^{\mathrm{a}}$ & $26.0 \pm 1.1^{\mathrm{a}, \mathrm{ns}}$ \\
Gestational age (week) at examination & - & - & $26.8 \pm 2.0$ & $26.4 \pm 1.7^{\mathrm{ns}}$ \\
At delivery & - & - & $39.1 \pm 0.3$ & $38.9 \pm 0.3^{\mathrm{ns}}$ \\
Mean birth weight (g) & - & - & $3,332 \pm 93.1$ & $3,224 \pm 145.5^{\mathrm{b}}$ \\
Sex of newborns (female/male) & - & - & $5 / 8$ & $8 / 13$ \\
\hline
\end{tabular}

$B M I$ body mass index

${ }^{\text {a }} p<0.05$ vs. the healthy non-pregnant group

${ }^{\mathrm{b}} p<0.05$ vs. the healthy pregnant group, $n s$ not significant vs. the appropriate healthy group 
Mean body mass index (BMI) was significantly greater in asthmatic than healthy non-pregnants (Table 2). No such difference was observed between the two pregnant groups. The mean gestational age at pulmonary examination was about 26th week in both healthy and asthmatic pregnant women. The mean gestational age at delivery was also similar (Table 2). Birth weight of newborns of asthmatic mothers was slightly lower as compared to healthy controls $(p<0.05)$. Peak expiratory flow was significantly reduced in both asthmatic groups (non-pregnant and pregnant) relative to predicted control values ( $p<0.05$, Table 3 ). Nonpregnant and pregnant asthmatics had similar degrees of airway obstruction and hypoxaemia (Table 3). Hypocapnia of both non-pregnant and pregnant asthmatics was mild. $\mathrm{pCO}_{2}$ of asthmatic pregnants was significantly $(p<0.001)$ lower than in non-pregnants, but within the reference range of $\mathrm{pCO}_{2}$ of healthy pregnants $(28-32 \mathrm{mmHg}$, [34]). Impaired maternal airway function and reduced birth weights showed no statistically significant relationship. Gender of the newborn had no influence on any clinical parameters of asthmatic pregnants. Nine non-pregnant and 11 pregnant asthmatics were treated with inhaled corticosteroid (ICS). The daily doses of various anti-asthma medications used are also shown in Table 3. All asthmatics were stable, none of them suffered from exacerbation.

Healthy and asthmatic pregnant patients had significantly lower red blood cell count compared to healthy and asthmatic non-pregnants $(4.10 \pm 0.09$ and $4.17 \pm 0.11 \mathrm{vs.}$ $4.80 \pm 0.09$ and $4.63 \pm 0.09 \mathrm{~T} / \mathrm{l}$, respectively), but all values were in the appropriate reference ranges [35]. Both, healthy and asthmatic pregnant groups had significantly $(p<0.01)$ higher neutrophil counts compared to appropriate groups of non-pregnants $(7.47 \pm 0.47$ and $7.86 \pm 0.60$ vs. $4.71 \pm 0.55$ and $4.37 \pm 0.39 \mathrm{G} / \mathrm{l}$, respectively). Eosinophil numbers were slightly but not statistically elevated in both, the non-pregnant and pregnant asthmatic groups.

\section{Lymphocyte activation}

\section{Non-pregnant asthmatics versus non-pregnant healthy subjects}

Nearly all measured subpopulations of lymphocytes within $\mathrm{T}\left(\mathrm{CD}^{+}\right)$and $\mathrm{B}\left(\mathrm{CD} 19^{+}\right)$cells had greater activated fractions in asthmatic than non-pregnant healthy subjects (Tables 4, 5). Larger fractions of $\mathrm{CD} 25^{+}$and $\mathrm{CD} 95^{+} \mathrm{T}$ cells, and larger $\mathrm{CD} 25^{+}, \mathrm{CD} 28^{+}$or $\mathrm{CD} 54^{+}$fractions of $\mathrm{CD} 4^{+}$cells were observed. The number of $\mathrm{CD} 54^{+}$and $\mathrm{CD}_{11} \mathrm{~b}^{+}$subsets within $\mathrm{CD} 8^{+}$cells and that of activated, $\mathrm{CD}^{+} 1^{+} \mathrm{B}$ cells also increased (Table 5). The size of the $\mathrm{NK}\left(\mathrm{CD} 3^{-} \mathrm{CD} 16^{+} \mathrm{CD} 56^{+}\right)$pool remained unchanged, but the number of $\mathrm{NK} \mathrm{T}\left(\mathrm{CD} 3^{+} \mathrm{CD} 16^{+} \mathrm{CD} 56^{+}\right)$cells were increased in non-pregnant asthmatic versus healthy individuals (Table 4). These results indicated activation of $\mathrm{T}$ and B lymphocytes, as well as an increased pool of NK T cells in peripheral blood of patients with mild to moderate persistent asthma.

\section{Healthy pregnants versus healthy non-pregnants}

According to several markers tested, normal pregnancy was a state of widespread lymphocyte activation (Tables 4, 5). The number of $\mathrm{CD} 25^{+}$and $\mathrm{CD} 95^{+} \mathrm{T}$ cells, $\mathrm{CD} 25^{+}$or

Table 3 Clinical data of asthmatic patients (non-pregnant and pregnant; means \pm SEM, where appropriate)

\begin{tabular}{|c|c|c|}
\hline & Asthmatic non-pregnant (12) & Asthmatic pregnant (21) \\
\hline Distribution of asthma severity (GINA II/III) & $8 / 4$ & $17 / 6^{\mathrm{ns}}$ \\
\hline PEF ( $\%$ of predicted) & $72.08 \pm 5.41^{*}$ & $72.5 \pm 3.16^{*}$ \\
\hline $\mathrm{FEV}_{1}(\%$ of predicted $)$ & $86.00 \pm 5.59$ & $87.62 \pm 3.24$ \\
\hline$R_{\mathrm{aw}}(\mathrm{kPa} \times \mathrm{s} / \mathrm{l})$ & $0.34 \pm 0.06^{\$}$ & $0.27 \pm 0.03^{\$}$ \\
\hline $\mathrm{pO}_{2}(\mathrm{mmHg})$ & $84.03 \pm 3.4^{*}$ & $88.35 \pm 2.12 *$ \\
\hline $\mathrm{pCO}_{2}(\mathrm{mmHg})$ & $35.47 \pm 0.75^{*}$ & $30.93 \pm 0.49 *$ \\
\hline $\mathrm{pH}$ & $7.52 \pm 0.01^{\$}$ & $7.51 \pm 0.01^{\$}$ \\
\hline Number of patients on inhaled corticosteroid (ICS) & 9 & $11^{\mathrm{ns}}$ \\
\hline Number of patients on inhaled long-acting $\beta_{2}$-agonist (LABA) & 4 & $4^{\mathrm{ns}}$ \\
\hline Daily dose of inhaled short-acting $\beta_{2}$-agonist (puffs) & $2(0,4)^{\mathrm{a}}$ & $2(0,4)^{\mathrm{a}}$ \\
\hline Daily dose of inhaled formoterol $(\mu \mathrm{g})$ & 11.25 & $10.13^{\mathrm{ns}}$ \\
\hline Daily dose of inhaled corticosteroid (beclomethasone equivalent $\mu \mathrm{g}$ ) & $587 \pm 74$ & $781 \pm 120^{\mathrm{ns}}$ \\
\hline
\end{tabular}

GINA global initiative for asthma, $P E F$ peak expiratory flow; Raw-airway resistance; $p O_{2}$ partial pressure of oxygen in arterialized capillary blood; $\mathrm{pCO}_{2}$ partial pressure of carbon-dioxide in arterialized capillary blood; $\mathrm{FEV}_{1}$-forced expiratory volume in one-second, $n s$ non significant vs. non-pregnant astmatics; *less or ${ }^{\$}$ more than the healthy age matched population mean $\pm 2 \times \mathrm{SD}$; ${ }^{\top}$ significant $(p<0.001)$ vs. asthmatic nonpregnant

${ }^{a}$ Median, smallest, largest. No significant differences among the two asthmatic groups except for $\mathrm{pCO}_{2}$ 
Table 4 Major lymphocyte sub-populations in peripheral blood of non-pregnant healthy and asthmatic subjects, and healthy and asthmatic pregnants (total numbers of cells/ $\mu$ l blood, means \pm SEM)

\begin{tabular}{llllll}
\hline $\begin{array}{l}\text { Lymphocyte } \\
\text { subset }\end{array}$ & Immuno-phenotype & $\begin{array}{l}\text { Healthy non-pregnant } \\
(n=10)\end{array}$ & $\begin{array}{l}\text { Asthmatic non-pregnant } \\
(n=12)\end{array}$ & $\begin{array}{l}\text { Healthy pregnant } \\
(n=13)\end{array}$ & $\begin{array}{l}\text { Asthmatic pregnant } \\
(n=21)\end{array}$ \\
\hline T cells & $\mathrm{CD}^{+}$ & $1,325 \pm 118.1$ & $1,586 \pm 134.8$ & $1,405 \pm 60.3$ & $1,256 \pm 61.9$ \\
T-helper cells & $\mathrm{CD}^{+} \mathrm{CD}^{+}$ & $777.2 \pm 92.4$ & $947.3 \pm 94.4$ & $764.7 \pm 35.0$ & $771.9 \pm 42.1$ \\
T-cytotoxic cells & $\mathrm{CD}^{+} \mathrm{CD}^{+}$ & $453.1 \pm 43.3$ & $554.9 \pm 62.6$ & $557.8 \pm 39.1$ & $435.3 \pm 28.0$ \\
NK T cells & $\mathrm{CD}^{+} \mathrm{CD}^{+} 6^{+} \mathrm{CD}^{+} 6^{+}$ & $117.5 \pm 19.1$ & $238.1 \pm 27.0^{* *}$ & $200.6 \pm 20.4 *$ & $178.2 \pm 16.2$ \\
B cells & ${\mathrm{CD} 19^{+}}$ & $128.6 \pm 10.5$ & $183.1 \pm 22.9$ & $163.1 \pm 13.3$ & $174.3 \pm 14.4$ \\
NK cells & $\mathrm{CD}{ }^{-} \mathrm{CD} 16^{+} \mathrm{CD} 56^{+}$ & $256.2 \pm 56.1$ & $296.1 \pm 73.9$ & $233.1 \pm 49.1$ & $300.8 \pm 45.1$ \\
\hline
\end{tabular}

Statistical analysis: ANOVA and Newman-Keuls comparison post-hoc test were applied if possible. " $p<0.05$ vs. asthmatic non-pregnant; $* p<0.05 ; * * p<0.01$ vs. healthy non-pregnant

Table 5 Distribution of activated lymphocyte sub-populations in peripheral blood of non-pregnant healthy and asthmatic subjects and healthy, or asthmatic pregnants (total numbers of cells $/ \mu$ l blood; means \pm SEM)

\begin{tabular}{lcllc}
\hline Immuno-phenotype & $\begin{array}{l}\text { Healthy non-pregnant } \\
(n=10)\end{array}$ & $\begin{array}{l}\text { Asthmatic non-pregnant } \\
(n=12)\end{array}$ & $\begin{array}{l}\text { Healthy pregnant } \\
(n=13)\end{array}$ & $\begin{array}{l}\text { Asthmatic pregnant } \\
(n=21)\end{array}$ \\
\hline $\mathrm{CD}^{+} \mathrm{CD} 25^{+}$ & $155.0 \pm 23.6$ & $288.8 \pm 29.1^{* *}$ & $240.4 \pm 19.3^{*}$ & $244.7 \pm 23.3$ \\
$\mathrm{CD}^{+} \mathrm{CD} 95^{+}$ & $344.5 \pm 39.3$ & $708.7 \pm 72.5^{* *}$ & $573.7 \pm 72.8^{*}$ & $580.5 \pm 54.7$ \\
$\mathrm{CD}^{+} \mathrm{HLADR}^{+}$ & $26.77 \pm 6.8$ & $33.11 \pm 6.5$ & $35.56 \pm 7.7$ & $23.43 \pm 2.2$ \\
$\mathrm{CD}^{+} \mathrm{CD} 25^{+}$ & $126.1 \pm 20.3$ & $245.0 \pm 27.6^{*}$ & $207.2 \pm 16.3^{*}$ & $222.0 \pm 22.3$ \\
$\mathrm{CD}^{+} \mathrm{CD} 28^{+}$ & $619.94 \pm 109.2$ & $972.9 \pm 120.7^{*}$ & $736.0 \pm 30.3$ & $703.6 \pm 45.9$ \\
$\mathrm{CD}^{+} \mathrm{CD} 54^{+}$ & $73.9 \pm 13.9$ & $193.1 \pm 32.8^{*}$ & $126.2 \pm 18.3$ & $192.6 \pm 26.8$ \\
$\mathrm{CD} 4^{+} \mathrm{CD} 1 b^{+}$ & $28.5 \pm 5.2$ & $53.58 \pm 13.3$ & $91.78 \pm 20.9 *$ & $51.57 \pm 10.9$ \\
$\mathrm{CD} 8^{+} \mathrm{CD} 25^{+}$ & $22.7 \pm 3.6$ & $45.08 \pm 8.4$ & $34.44 \pm 9.3$ & $30.10 \pm 4.2$ \\
$\mathrm{CD} 8^{+} \mathrm{CD} 28^{+}$ & $295.7 \pm 34.9$ & $368.7 \pm 41.0$ & $278.6 \pm 28.9$ & 28.9 \\
$\mathrm{CD} 8^{+} \mathrm{CD} 54^{+}$ & $74.02 \pm 13.87$ & $193.2 \pm 32.8^{*}$ & $249.2 \pm 36.0^{*}$ & $274.2 \pm 30.8$ \\
$\mathrm{CD} 8^{+} \mathrm{CD} 1 b^{+}$ & $116.1 \pm 15.2$ & $215.2 \pm 25.2^{*}$ & $105.6 \pm 12.9^{*}$ & $220.0 \pm 22.8$ \\
$\mathrm{CD} 19^{+} \mathrm{CD} 71^{+}$ & $44.2 \pm 6.9$ & $100.5 \pm 22.1^{*}$ & & $55.0 \pm 9.0^{\$}$ \\
\hline
\end{tabular}

${ }^{*} p<0.05 ; * * p<0.01$ vs. healthy non-pregnants; ${ }^{\$} p<0.05$ vs. healthy pregnants

$\mathrm{CD}_{11 \mathrm{~b}^{+}} \mathrm{CD}^{+}$cells, $\mathrm{CD} 54^{+}$or $\mathrm{CD} 11 \mathrm{~b}^{+} \mathrm{CD} 8^{+}$cells, $\mathrm{NK}$ $\mathrm{T}$ cells and $\mathrm{CD} 71^{+} \mathrm{B}$ cells were all significantly higher in healthy pregnant compared to healthy non-pregnant women. Direct correlation $(p<0.01)$ was revealed between the $\mathrm{CD} 5^{+} \mathrm{T}$ cell count and birth weight.

\section{Pregnant asthmatics versus other groups}

In pregnant asthmatic patients, the size of activated pools of most lymphocyte subsets remained unchanged relative to those in healthy pregnants (Tables 4,5 ). The CD71 ${ }^{+} \mathrm{B}$ cell population was, however, smaller in asthmatic versus healthy pregnants.

Multiple linear regression analyses were performed between the sizes of various activated lymphocyte pools and airway parameters or birth weights. Higher number of circulating $\mathrm{CD}^{+} \mathrm{CD}^{+}, \mathrm{CD}^{+}{ }^{+} \mathrm{HLADR}^{+}$, and $\mathrm{CD} 8^{+} \mathrm{CD} 28^{+}$ lymphocytes displayed indirect linear correlations with $\mathrm{FEV}_{1}$; higher $\mathrm{CD} 3^{+} \mathrm{HLADR}^{+}$and $\mathrm{CD} 8^{+} \mathrm{CD} 28^{+}$numbers showed direct linear correlation with Raw; and higher $\mathrm{CD} 8^{+} \mathrm{CD} 28^{+}$cell counts presented indirect linear correlation with $\mathrm{pO}_{2}$. It became clear, however, that several linear regressions reached statistical significance because of 2 (out of the 21) pregnant asthmatics who demonstrated the most severe clinical abnormalities as well as most activated lymphocytes. One of these 2 pregnant asthmatics had the most severe airway obstruction $\left(\mathrm{FEV}_{1}: 38 \%\right)$, the largest pools of $\mathrm{CD}^{+} \mathrm{CD}^{+}, \mathrm{CD}^{+} \mathrm{HLADR}^{+}, \mathrm{CD}^{+} \mathrm{CD} 28^{+}$cells and gave birth (at term) to her newborn with smaller than average body weight $(2650 \mathrm{~g})$. The other asthmatic pregnant patient delivered the most growth retarded $(1,690 \mathrm{~g})$ newborn (35th week of gestation) and also had very high numbers of activated lymphocytes $\left(\mathrm{CD} 3^{+} \mathrm{CD} 25^{+}\right.$, $\mathrm{CD} 4^{+} \mathrm{CD} 25^{+}, \mathrm{CD}^{+} \mathrm{CD} 25^{+}$), meanwhile demonstrating smaller than average $\mathrm{FEV}_{1}$. Leaving out the two highest lymphocyte and lowest $\mathrm{FEV}_{1}$ values belonging to those asthmatic mothers who gave birth to the smallest newborns led to loss of statistical significance. The same applied to the 
indirect correlation between $\mathrm{CD} 3^{+} \mathrm{CD} 28^{+}, \mathrm{CD} 8^{+} \mathrm{CD} 25^{+}$, or $\mathrm{CD} 4{ }^{+} \mathrm{CD} 25^{+}$cellular pools and birth weights. The BMI was not correlated with the size of any lymphocyte subsets, $\mathrm{FEV}_{1}$, Raw, $\mathrm{pO}_{2}$ or birth weight.

\section{Discussion}

The course of several immunological diseases improves [15-17] during pregnancy and in at least one-third of asthmatic women asthma symptoms become temporarily reduced during pregnancy [13]. One possible mechanism of these phenomena is pregnancy-induced immunotolerance. Maternal immunotolerance is necessary for mammalian reproduction. HLA-G expressed on the syntitiotrophoblast binds NK cells and inhibits killing; placental indoleamine 2,3-dioxygenase consumes tryptophan in the vicinity of placental effector $\mathrm{T}$ cells, which become paralysed due to tryptophan deficiency; and the placenta synthesizes progesterone and placental growth hormone, both of which inhibit immune response [28]. In addition, apoptotic $\mathrm{T}$ cells are detected in human decidua; the specific ligand of CD95 is expressed on trophoblasts and there is CD95 on many activated maternal $\mathrm{T}$ cells, which enter into contact with the conceptus. The present study confirmed the existence of a direct, quantitative relationship between the number of preapoptotic $\left(\mathrm{CD} 5^{+}\right) \mathrm{T}$ cells and birth weight in healthy, but not in asthmatic, pregnants.

According to Aluvihare et al. [29], regulatory T cells mediate maternal tolerance to the fetus. Foxp3 mRNA content is 1,000-fold higher in the pregnant than in the nonpregnant uterine wall [29], which probably reflects accumulation of Treg cells in the decidua. Absence of this lymphocyte subgroup causes rejection of the fetus [29]. During physiologic pregnancy, estradiol boosts the suppressive function of Treg cells by promoting their antigen independent proliferation [30]. Immunologic tolerance mediated by Treg cells during pregnancy can be antigen independent [29] and during pregnancy tolerance is not only expressed towards fetal (paternal) antigens, but autoantigens as well $[15,36]$. The Treg subpopulation of lymphocytes is spread all over the maternal organism, peripheral blood [37, 38], spleen and thymus [39]. Immunological tolerance during pregnancy is also observed remote from the intrauterine environment [40]. Accordingly, splenocytes of primiparous mice proliferate following exposure to fetal cells, whereas those of virgin mice do not [41]. Anti-idiotypic (anti-paternal HLA specific T cell receptor) antibodies can be recovered from circulating plasma of previously pregnant women [42]. Based on these considerations we raised the hypothesis that pregnancy might reduce allergic airway inflammation via pregnancy- induced, bystander, or linked immunologic tolerance. The present findings supported this hypothesis, because in almost no pregnant mild or moderate, persistant asthmatic patients was there any additive activation of $\mathrm{T}$ or $\mathrm{B}$ cells, or culminating numbers of NK T lymphocytes.

The interaction of asthma and pregnancy may depend on severity of asthma or other maternal complications during pregnancy. There was an association between obesity and asthma. Asthma is more prevalent among obese subjects [43], and obesity is more frequently associated with a difficult-to-control phenotype of asthma [44]. Within mild-to-moderate persistent asthmatics, however, increased BMI is not associated with worse clinical symptoms [45]. According to secondary analysis of the prospective cohort in the Asthma During Pregnancy Study, obesity is associated with an increased risk of exacerbations during pregnancy [46]. In our present study the body mass index was also significantly higher in non-pregnant asthmatic versus healthy women, but no major difference was found between the two pregnant groups. All our patients suffered from mild-to-moderate persistent asthma. In accordance with previous publications $[45,46]$ in these patients BMI and lung function were not related. Within the pregnant asthmatics group, those two patients who had the most severe airway obstruction were also outlyers regarding the body weight of newborns and pools of activated lymphocytes. In our previous study [14] we had three such patients suffering from severe asthma and preeclampsia and also presenting large fractions of lymphocytes synthesizing interferon- $\gamma$. They also delivered at term, but their newborns were very small $(1,000-1,500 \mathrm{~g})$. It remains a question whether major immunological activation in more severe asthma during pregnancy may cause severe fetal growth retardation, or whether other maternal complications which are responsible for severe retardation of fetal growth (e.g. chorioamnionitis) also worsen asthma.

In conclusion, the analysed lymphocyte subpopulations were activated both in healthy pregnancy and asthma. In asthmatic pregnants with mild or moderate persistent disease, however, no additive increase in counts of activated lymphocytes was observed. This may indicate the existence of pregnancy-induced moderation of lymphocyte activation associated with allergic asthma.

Acknowledgment This work was supported by grants from OTKA (68758/07), ETT (371/06) and Semmelweis University. Authors are grateful to dr. Ildikó Horváth for her advice during the writing of this manuscript.

Open Access This article is distributed under the terms of the Creative Commons Attribution Noncommercial License which permits any noncommercial use, distribution, and reproduction in any medium, provided the original author(s) and source are credited. 


\section{References}

1. Corrigan CJ. T lymphocytes in asthma pathogenesis. In: Barnes PJ, editor. Asthma. Philadelphia: Lippincott-Raven; 1997. p. $433-51$.

2. Corrigan CJ, Kay AB. CD4 T-lymphocyte activation in acute severe asthma: relationship to disease severity and atopic status. Am Rev Respir Dis. 1990;141:970-7.

3. Corrigan CJ, Hartnell A, Kay AB. T lymphocyte activation in acute severe asthma. Lancet. 1988;1:1129-32.

4. Walker C, Kaegi MK, Braun P, Blaser K. Activated T cells and eosinophilia in bronchoalveolar lavages from subjects with asthma correlated with disease severity. J Allergy Clin Immunol. 1991;88:935-42.

5. Tong J, Bandulwala HS, Clay BS, Anders RA, Shilling RA, Balachandran DD, et al. Fas-positive $T$ cells regulate the resolution of airway inflammation in a murine model of asthma. J Exp Med. 2006;203:1173-84.

6. Wong CK, Lun SW, Ko FW, Ip WK, Hui DS, Lam CW. Increased expression of plasma and cell surface co-stimulatory molecules CTLA-4, CD28 and CD86 in adult patients with allergic asthma. Clin Exp Immunol. 2005;141:122-9.

7. De RV, Rolla G, Bucca C, Ghio P, Bertoletti M, Baderna P, et al. Intercellular adhesion molecule-1 is upregulated on peripheral blood T lymphocyte subsets in dual asthmatic responders. J Clin Invest. 1994;94:1840-5.

8. Barklay AN, Bentley AM, Hartnell A, Kay AB, Durham SR, editors. The leukocyte antigen facts book. New York: Academic Press, 1997.

9. Robinson DS, Bentley AM, Hartnell A, Kay AB, Durham SR. Activated memory $\mathrm{T}$ helper cells in bronchoalveolar lavage fluid from patients with atopic asthma: relation to asthma symptoms, lung function, and bronchial responsiveness. Thorax. 1993;48: 26-32.

10. Corrigan CJ, Haczku A, Gemou-Engesaeth V, Doi S, Kikuchi Y, Takatsu $\mathrm{K}$, et al. CD4 T-lymphocyte activation in asthma is accompanied by increased serum concentrations of interleukin-5: effect of glucocorticoid therapy. Am Rev Respir Dis. 1993;147: 540-7.

11. National Institutes of Health. National Heart, Lung, and Blood Institute Data Fact Sheet: Asthma Statistics. Bethesda: NIH, 1999.

12. Tan KS, Thomson NC. Asthma in pregnancy. Am J Med. 2000; 109:727-33.

13. Murphy VE, Clifton VL, Gibson PG. Asthma exacerbations during pregnancy: incidence and association with adverse pregnancy outcomes. Thorax. 2006;61:169-76.

14. Tamasi L, Bohacs A, Pallinger E, Falus A, Rigo J Jr, Muller V, et al. Increased interferon-gamma- and interleukin-4-synthesizing subsets of circulating T lymphocytes in pregnant asthmatics. Clin Exp Allergy. 2005;35:1197-203.

15. Mattsson R, Mattsson A, Holmdahl R, Whyte A, Rook GA. Maintained pregnancy levels of oestrogen afford complete protection from post-partum exacerbation of collagen-induced arthritis. Clin Exp Immunol. 1991;85:41-7.

16. Ostensen M, Villiger PM. Immunology of pregnancy-pregnancy as a remission inducing agent in rheumatoid arthritis. Transpl Immunol. 2002;9:155-60.

17. Amino N, Tada H, Hidaka Y. Autoimmune thyroid disease and pregnancy. J Endocrinol Invest. 1996;19:59-70.

18. Trowsdale J, Betz AG. Mother's little helpers: mechanisms of maternal-fetal tolerance. Nat Immunol. 2006;7:241-6.

19. Kuhnert M, Strohmeier R, Stegmuller M, Halberstadt E. Changes in lymphocyte subsets during normal pregnancy. Eur J Obstet Gynecol Reprod Biol. 1998;76:147-51.
20. Mahmoud F, Abul H, Omu A, Haines D. Lymphocyte sub-populations in gestational diabetes. Am $\mathrm{J}$ Reprod Immunol. 2005;53:21-9.

21. Mahmoud F, Omu A, Abul H, El-Rayes S, Haines D. Lymphocyte subpopulations in pregnancy complicated by hypertension. J Obstet Gynaecol. 2003;23:20-6.

22. Mahmoud F, Abul H, Omu A, Al-Rayes S, Haines D, Whaley K. Pregnancy-associated changes in peripheral blood lymphocyte subpopulations in normal Kuwaiti women. Gynecol Obstet Invest. 2001;52:232-6.

23. Luppi P, Haluszczak C, Trucco M, DeLoia JA. Normal pregnancy is associated with peripheral leukocyte activation. Am J Reprod Immunol. 2002;47:72-81.

24. Slukvin II, Chernyshov VP, Merkulova AA, Vodyanik MA, Kalinovsky AK. Differential expression of adhesion and homing molecules by human decidual and peripheral blood lymphocytes in early pregnancy. Cell Immunol. 1994;158:29-45.

25. van Kampen CA, Versteeg-vd Voort Maarschalk MF, LangerakLangerak J, Roelen DL, Claas FH. Kinetics of the pregnancyinduced humoral and cellular immune response against the paternal HLA class I antigens of the child. Hum Immunol. 2002;63:452-8.

26. Meeusen EN, Bischof RJ, Lee CS. Comparative T-cell responses during pregnancy in large animals and humans. Am J Reprod Immunol. 2001;46:169-79.

27. Bouma GJ, van CP, van Bree SP, Castelli-Visser RM, Witvliet MD, van der Meer-Prins EM, et al. Pregnancy can induce priming of cytotoxic T lymphocytes specific for paternal HLA antigens that is associated with antibody formation. Transplantation. 1996;62:672-8.

28. Thellin O, Coumans B, Zorzi W, Igout A, Heinen E. Tolerance to the foeto-placental 'graft': ten ways to support a child for nine months. Curr Opin Immunol. 2000;12:731-7.

29. Aluvihare VR, Kallikourdis M, Betz AG. Regulatory T cells mediate maternal tolerance to the fetus. Nat Immunol. 2004;5: 266-71.

30. Prieto GA, Rosenstein Y. Oestradiol potentiates the suppressive function of human $\mathrm{CD} 4 \mathrm{CD} 25$ regulatory $\mathrm{T}$ cells by promoting their proliferation. Immunology. 2006;118:58-65.

31. Pocket guide for asthma management and prevention. global initiative for asthma, updated 2006. http://www.ginasthma com.

32. http://www.bdbiosciences.com/pharmingen/protocols/LysedWhole BloodMethod.shtml.

33. Brando B, Barnett D, Janossy G, Mandy F, Autran B, Rothe G, et al. Cytofluorometric methods for assessing absolute numbers of cell subsets in blood: European working group on clinical cell analysis. Cytometry. 2000;42:327-46.

34. Wise RA. Pulmonary function during pregnancy. In: Schatz M, Zeiger RS, Claman HN, editors. Asthma and immunological diseases in pregnancy and early infancy. New York: Marcel Dekker Inc; 1998. p. 57-73.

35. Letsky EA. Blood volume, haematinics, anaemia. In: de Swiet M, editor. Medical disorders in obstetric practice. Oxford: Blackwell; 1995. p. 33-77.

36. Beagley KW, Gockel CM. Regulation of innate and adaptive immunity by the female sex hormones oestradiol and progesterone. FEMS Immunol Med Microbiol. 2003;38:13-22.

37. Saito S, Sasaki Y, Sakai M. CD4(+)CD25high regulatory T cells in human pregnancy. J Reprod Immunol. 2005;65:111-20.

38. Somerset DA, Zheng Y, Kilby MD, Sansom DM, Drayson MT. Normal human pregnancy is associated with an elevation in the immune suppressive $\mathrm{CD} 25+\mathrm{CD} 4+$ regulatory $\mathrm{T}$-cell subset. Immunology. 2004;112:38-43.

39. Zenclussen AC, Gerlof K, Zenclussen ML, Ritschel S, Zambon BA, Fest $S$, et al. Regulatory $\mathrm{T}$ cells induce a privileged tolerant 
microenvironment at the fetal-maternal interface. Eur J Immunol. 2006;36:82-94.

40. McCracken SA, Gallery E, Morris JM. Pregnancy-specific downregulation of NF-kappa B expression in T cells in humans is essential for the maintenance of the cytokine profile required for pregnancy success. J Immunol. 2004;172:4583-91.

41. Hoskin DW, Murgita RA. Specific maternal anti-fetal lymphoproliferative responses and their regulation by natural immunosuppressive factors. Clin Exp Immunol. 1989;76:262-7.

42. Suciu-Foca N, Reed E, Rohowsky C, Kung P, King DW. Antiidiotypic antibodies to anti-HLA receptors induced by pregnancy. Proc Natl Acad Sci USA. 1983;80:830-4.

43. Camargo CA Jr, Weiss ST, Zhang S, Willett WC, Speizer FE. Prospective study of body mass index, weight change, and risk of adult-onset asthma in women. Arch Intern Med. 1999;159:2582-8.
44. Dolan CM, Fraher KE, Bleecker ER, Borish L, Chipps B, Hayden ML, et al. Design and baseline characteristics of the epidemiology and natural history of asthma: outcomes and treatment regiments (TENOR) study: a large cohort of patients with severe or difficult-to-treat asthma. Ann Allergy Asthma Immunol. 2004;92:32-9.

45. Sutherland ER, Lehman EB, Teodorescu M, Wechsler ME. Body mass index and phenotype in subjects with mild-to-moderate persistent asthma. J Allergy Clin Immunol. 2009;123:1328-34.

46. Hendler I, Schatz M, Momirova V, Wise R, Landon M, Mabie W, et al. Association of obesity with pulmonary and nonpulmonary complications of pregnancy in asthmatic women. Obstet Gynecol. 2006; $108: 77-82$. 